\title{
The Influence of Income Level, Financial Literature, and Social Media Use on Teachers Consumption Behavior
}

\author{
Nur Hidayati ${ }^{1,2 *}$, Sri Kartikowati ${ }^{2}$, Gimin $^{2}$ \\ ${ }^{1}$ SMA Negeri 1 Sabak Auh, Siak, 28684, Indonesia \\ ${ }^{2}$ Economic Education Studies Program FKIP, Riau University, Pekanbaru, 28293, Riau, Indonesia
}

\section{ARTICLE INFO}

\section{Article history:}

Received: 14 May 2021

Revised: 15 June 2021

Accepted: 20 June 2021

Published online: 24 July 2021

\section{Keywords:}

Income Level

Financial Literacy

Social Media

Consumptive Behavior

\begin{abstract}
A B S T R A C T
This study aims to identify and analyze the influence of income level, financial literacy, use of social media; on the consumptive behavior of teachers. The total population in this study was 127 civil servant teachers. The sampling technique used Isaac Michael's table with an error rate of $5 \%$, the number of samples in this study was 94 teachers. The process of taking sample data using proportional random sampling technique. Data was obtained by using questionnaires and documentation methods. The collected data was then analyzed using descriptive analysis and multiple regression analysis. The findings in this study are that there is no significant effect of the income level variable on the consumptive behavior of teachers, there is a significant influence of the financial literacy variable and the use of social media on the consumptive behavior of PNS teachers. The level of consumptive behavior is related to the financial literacy of teachers and the use of social media. So that teachers are expected to increase their level of financial literacy and reduce the intensity in using social media to minimize consumptive behavior.
\end{abstract}

\section{Introduction}

The development of digitalization, automation and industrialization in the era of the industrial revolution 4.0 is currently having an impact on the increasingly rapid world trade so as to make the flow of goods and services move faster. This results in higher levels of consumption in the community. In the beginning, consumption was carried out with the aim of meeting needs. However, nowadays consumption has lost its function, consumption is no longer done to meet the needs of life but rather to satisfy desires. Consumption motives are more likely because emotional is no longer rational. It seems that today's society has difficulty distinguishing between needs and wants. The desire to buy a product that is 
excessive is the beginning of the emergence of consumptive behavior. Individuals will continuously buy goods based only on what they want, not on what is needed. Consumptive behavior is a human tendency to consume unlimited, buy something excessive or unplanned (Chita et al, 2015). The unplanned purchase of goods or services is caused by a lack of financial knowledge and not making a budget based on the priority scale.

We can find this in teachers in the Sabak Auh District, Siak Regency, Riau. Teachers should be role models for students and their living environment in various aspects including consumption activities, sometimes they actually behave consumptively by competing to show what they have either directly or through status posts on social media. As a result, needs such as the purchase of supporting books in learning, teaching facilities and infrastructure, and even the need to upgrade knowledge through various trainings are neglected. The increase in income earned does not automatically make teachers feel enough and in the end they will do all kinds of ways to fulfill these desires including by way of credit.

Based on the results of the researchers' observations of 10 teachers in the Sabak Auh sub-district, there were several teachers who had consumptive behavior characteristics, namely 4 teachers bought a product because the product was brought to school by a colleague at work, 2 teachers consumed the product for trial and error just because the product was viral, 3 teachers buy online products offered by colleagues because they are on discount, and 1 teacher only wants to buy certain brand products to maintain social status.

Sutriati (2018) in her research on the consumptive behavior of students majoring in Social Sciences FKIP Riau University (UR) showed that of 126 respondents, most of the respondents had consumptive behavior in the high category, namely 66 people $(52.4 \%)$ and even 6 people $(4,8 \%)$ respondents have a very high category of consumptive behavior. Someone who tends to be consumptive can cause problems. This is explained in Sutriati's research (2018) that if consumptive behavior continues to be carried out without any thought, it will result in wasteful actions where one cannot distinguish which ones are really needed and which ones are just wanted. They are even willing to sacrifice half the income they receive in order to get the desired product.

In terms of consumption, Islam also teaches to be simple, not extravagant, and not excessive because waste is the brothers of Satan. As stated in the Word of Allah SWT in Surah Al-Isro verse 27 which means: "Indeed, the spenders are the brothers of Satan and the devil is a complete disbeliever in his Lord". In addition, the limits of consumptive behavior are also stated in the letter al-Furqaan verse 67 which means "And those who, when they spend (wealth), they are not excessive, and are not (also) miserly, and are (the spending) in the middle middle of that.

Consumptive behavior is prone to be carried out by all groups including teachers and this can happen due to several factors. Consumptive behavior in consuming a product is influenced by internal factors and external factors. Internal factors 
include motivation, personality, economy (income, future forecasts). External factors include culture, lifestyle and reference groups (Ahmad, 2012).

One of the factors that cause consumptive behavior is economic factors, namely income. According to Gumanti et al (2017) changes in consumer behavior in consuming goods and services can change along with an increase in income. Income is all money received by individuals within a certain period of time (Gumanti, 2017). The income of PNS teachers is obtained from salaries, Additional Employee Income (TPP), certification, and income from business fields owned outside the teaching profession. Basically, civil servant teachers already have more than high enough income because in addition to salary, civil servant teachers also get TPP and even certification money. However, what generally happens is that their finances are still insufficient to meet their daily needs.

Large money resources are not a guarantee of welfare if they are not managed properly (Kurniadi et al, 2018). One of the causes of financial problems experienced by teachers is the inaccuracy of financial management which is closely related to the level of financial literacy or financial literacy owned by teachers. Financial literacy or what is commonly called financial literacy is the ability to understand how money works, how someone manages to get it, how people can manage it, and how one can invest it or turn it into more (Prihastuti, 2018). Financial knowledge plays an important role in overcoming the phenomenon of low personal financial management skills. Mawo et al. (2017) found that financial literacy had a negative effect on students' consumptive behavior. So, the better a person's financial literacy, the wiser he will be in carrying out consumption activities. Tsalitsa's research (2016) also finds that financial literacy and income have a positive influence on credit-making decisions.

Another factor that can influence a person to behave consumptively is the use of social media. Social media is a medium to socialize with each other that allows humans to interact with each other without being limited by space and time (Antow, 2016). The presence of social media is not only used as a communication medium, but also used by producers of goods or services to promote their wares through social media sites (Khoiriyah, 2020). Hidayanti et al (2017) found that the use of social media had a positive and significant effect on the consumptive behavior of students of the 2016 PGRI University Economics Education Study Program. Research by Anggraeni \& Setiaji (2018) also found that social media such as Instagram has an influence on consumptive behavior. Social media or in Indonesian called social media is media designed to facilitate interactive or twoway social interactions (Putro, 2014).

The sophistication of technology and information today triggers producers to package their merchandise to become more attractive and marketable, and social media is an effective medium for promotion. All kinds and types of tools to satisfy needs can be easily found in advertisements offered on social media such as Facebook, Instagram, YouTube, and other social media. The use of social 
media by producers is more because the trend of using social media is very intensive lately.

The use of social media cannot be separated from the use of the internet which is a trend in various circles, including teachers. Internet users in Indonesia, based on a survey by the Indonesian Internet Network User Association, reached 171.17 million out of a total 264.16 million Indonesian population, meaning that around $64.8 \%$ of Indonesia's population is connected to the internet (APJII, 2018). From these data, it is known that the teaching profession ranks second out of 12 types of jobs that use the internet the most. This number is a fantastic number for producers to be used as a marketing business field.

For teachers who do not have the ability to distinguish between needs and desires, it will be difficult to control the use of social media because they only think about pleasure and satisfaction so they have the potential to be trapped in consumptive behavior. This study aims to determine the effect of the variables of income level, financial literacy, and use of social media on the consumptive behavior of civil servant teachers in Sabak Auh District, Siak Regency, Riau.

\section{Methodology}

This study used quantitative methods assisted by Microsoft Excel and SPSS vers 25. Data was collected using questionnaires, tests and documentation. The data analysis used descriptive quantitative for the population in this study were all civil servant teachers in Sabak Auh District. As many as 127 PNS teachers have been choosed using proportional random sampling technique and determining the number of samples using Isaac Mitchael's table with an error rate of 5\%, a sample of 94 PNS teachers in Sabak Auh District was obtained. Sources of data used in this study are primary and secondary data sources.

The income level variable consists of four indicators, namely income obtained from civil servant salaries, income obtained from additional employee income, income obtained from Teacher Professional Allowance (TPG) or certification, and income obtained from other income outside the teaching profession. The financial literacy variable consists of four indicators, namely general knowledge of finance, savings and loans, insurance, and investment. The variable use of social media consists of 4 indicators, namely attention, appreciation, duration, and frequency, and the consumptive behavior variable consists of three indicators, namely sudden purchases (impulsive buying), waste (Wasteful buying) and irrational buying (Non rational buying). each indicator is further broken down into several subindicators. The type of questionnaire used for the income variable uses openended questions, the financial literacy variable uses a test, while the variables of social media use and consumptive behavior use a Likert questionnaire.

The data analysis technique used in this research is descriptive analysis using categorization based on the mean and standard deviation of each variable, the categorization is very low, low, high and very high. The data analysis technique 
begins with the normality test which is carried out with the Kolmogrof Smirnof test, the linearity test to determine the linear relationship or not significantly between the independent variables and the dependent variable and the multicollinearity test to see whether there is a very strong relationship between the independent variables and the heteroscedasticity test to test similarity of error variance for each independent variable. Testing the influence of the independent variable on the dependent variable whether each variable has a positive or negative effect is carried out by multiple linear regression followed by the coefficient of determination test (R2) to measure how far the model's ability to explain the variation of the dependent variable.

\section{Results and Discussion}

Based on the results of statistical analysis research, it is known that from 94 respondents, most of them are female respondents, namely 73 people $(77.7 \%)$. While the rest are male respondents as many as 21 people $(22.3 \%)$. Based on the rank of the respondents, with the highest rank, 24 people (25.53\%) were in group III $b$ while the least respondents were in group II b with 1 person each (1.06\%). Judging from the certification status, the average respondent has been certified as many as 72 people (77\%) while the respondents who have not been certified are 22 people (23\%), the school level where the largest respondent teaches is in Elementary School (SD) as many as 66 people $(70,21 \%)$, while the respondents in terms of age are mostly 42 people (45\%) aged $41-50$ years while the age group $<30$ years is the least, namely 2 people $(2 \%)$. The social media used by 94 people $(100 \%)$ of respondents is Whatsapp (WA). Based on the business fields owned by teachers outside the profession and become a source of additional income, it turns out that teachers who do not have side businesses are more than 54 people (53\%), while those who have side businesses outside the profession are 40 people (47\%).

In addition, the results of the research on consumptive behavior instruments have an average value of 44.84 and a standard deviation of 8.987. The income instrument has an average value of 22.50 and a standard deviation of 4.50 . The financial literacy instrument has an average value of 54.63 and a standard deviation of 11.987 while the social media use instrument has an average value of 21.34 and a standard deviation of 4.219 . Thus, it can be concluded that three (three) of the 4 (four) data used can be classified as good data, this can be seen from the standard deviation value which is smaller than the mean (average value) of the variable data, except income level data which has a standard deviation value greater than the average value.

Next is the results of statistical analysis based on each variable, for the consumptive behavior variable category of 94 respondents, most of the respondents have a low level of consumptive behavior in the category of 51 out of 94 teachers or $54.3 \%$. Although there are those who have consumptive behavior in the very high category, the number is only $3.2 \%$. This means that teachers at the elementary, junior high, and high school levels in Sabak Auh sub-district, Siak district, Riau have consumptive behavior in the low category. The income 
variable shows that of the 94 respondents, it shows that all teachers have income in the very high category because all PNS teachers in Sabak Auh District, Siak Regency who are respondents in this study have an average income of more than Rp. 3,500,000.00 per month. The financial literacy variable shows that of the 94 respondents, most of the respondents have a low level of financial literacy, namely 56 people $(59.6 \%)$ while financial literacy in the medium category is 38 people $(40.4 \%)$ and no one has a high level of financial literacy. The variables of social media use show that of the 94 respondents, most of the respondents are in the low category, namely 48 people $(51.1 \%)$, although there are those who have social media use at high category but the number is only $37.2 \%$. This means that civil servant teachers in Sabak Auh District, Siak Regency, have low use of social media.

The normality test shows that the four research variables (income, financial literacy, and use of social media and consumptive behavior) each have Asymp. Sig is $0.064,0.080,0.200$ and 0.056 and is greater than 0.05 (decision-making provisions sig=0.05). This means that each of these variables is normally distributed and meets the assumption of normality, this indicates that the data collected has been able to represent the population and the results above, and the research can perform statistical analysis of existing data. The linearity test of the income level variable shows the Sig of Deviation from Linearity of $0.850>0.05$ (tolerance of 5\%). This means that income with consumptive behavior has a nonlinear relationship. While the financial literacy variable has a sig of $0.005<0.05$ and the use of social media has a Sig of Deviation from Linearity of $0.000<0.05$. This means that financial literacy with consumptive behavior has a linear relationship because the value of sig $<0.05$.

The multicollinearity test shows that the tolerance value of the income level variable is 0.979 , financial literacy is 0.981 and the use of social media is 0.993 , which means all are greater than 0.10 . So it can be concluded that there is no multicollinearity among the independent variables. The results of the heteroscedasticity test of this study can be seen in the scatterplot figure 1 . Figure 1 (scatterplot) shows that the scatterplot points do not form a pattern so that it can be concluded that the residuals escape from heteroscedasticity.

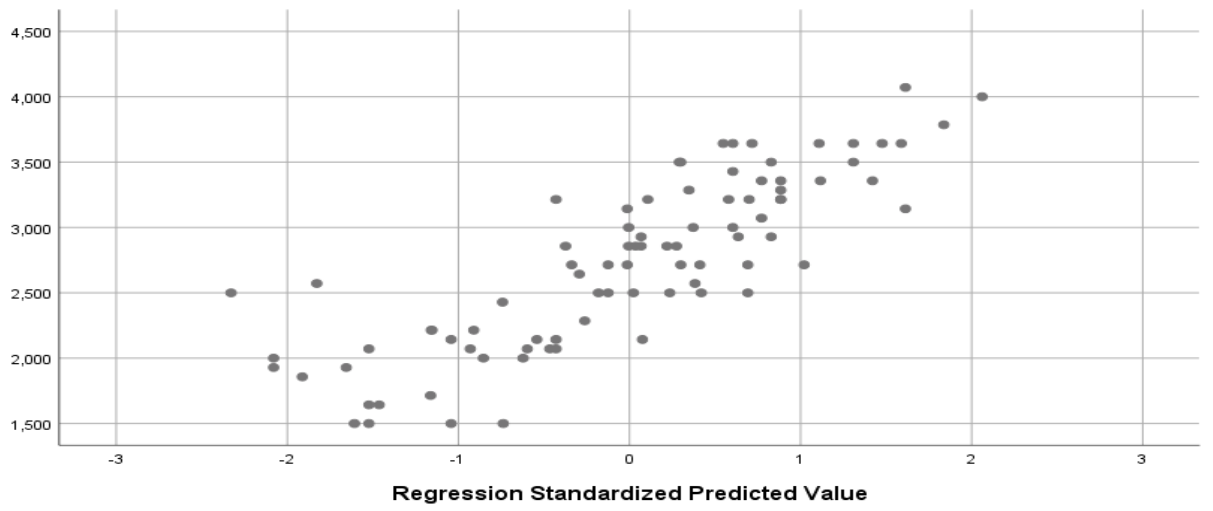

Figure 1 Heteroscedasticity Test Scatterplot Uji 
The results of the analysis using multiple linear regression can be seen in table 1 below:

Table 1. Partial Effects of Income Level Variables (X1), Financial Literacy (X2) and Use of Social Media (X3) on Consumptive Behavior (Y) of PNS Teachers in Sabak Auh District, Siak

\begin{tabular}{|c|c|c|c|c|c|c|}
\hline \multicolumn{7}{|c|}{ Coefficients $^{\mathrm{a}}$} \\
\hline \multirow{2}{*}{\multicolumn{2}{|c|}{ Model }} & \multicolumn{2}{|c|}{$\begin{array}{l}\text { Unstandardized } \\
\text { Coefficients }\end{array}$} & \multirow{2}{*}{$\begin{array}{c}\text { Standardized } \\
\text { Coefficients } \\
\text { Beta }\end{array}$} & \multirow[b]{2}{*}{$\mathrm{t}$} & \multirow[b]{2}{*}{ Sig. } \\
\hline & & B & Std. Error & & & \\
\hline 1 & (Constant) & 37,347 & 6,019 & & 6,204 & 0,000 \\
\hline & Income & $2,426 \mathrm{E}-7$ & 0,000 & 0,079 & 0,856 & 0,394 \\
\hline & Financial Literacy & $-0,238$ & 0,069 & $-0,318$ & $-3,443$ & 0,001 \\
\hline & Social media & 0,858 & 0,196 & 0,403 & 4,387 & 0,000 \\
\hline
\end{tabular}

a. Dependent Variable: Consumptive Behavior

From the table above, the regression equation can be written as follows

$\mathrm{Y}=37.347+0.0000002426 \mathrm{X} 1-0.238 \mathrm{X} 2+0.858 \mathrm{X} 3$

This means the following:

1. The number 37.347 means that if income, financial literacy, and use of social media are 0 (or none), then the amount of consumptive behavior of PNS teachers in Sabak Auh District, Siak Regency is 37.347 units from a range of 24 to 71 .

2. The number $0.0000002426 \mathrm{X} 1$ means that every change in teacher income of Rp.1, will change the consumptive behavior of PNS teachers in Sabak Auh District, Siak Regency by 0.0000002426 units.

3. The number $-0.238 \mathrm{X} 2$ means that each additional 1 unit of Financial Literacy will reduce (-) the consumptive behavior of PNS teachers in Sabak Auh District, Siak Regency by 0.238 units.

4. The number $0.858 \mathrm{X} 3$ means that if every additional 1 unit of intensity of use of social media by civil servant teachers in Sabak Auh District, Siak Regency, Riau will increase consumptive behavior by 0.8858 units.

Based on the $t$ test with a significant level of $5 \%$ can be seen as follows:

1. The income variable on consumptive behavior is known to be sig. $(0.394)>0.05$. This means that the income variable has no effect on consumptive behavior.

2. The variable of financial literacy on consumptive behavior is known to be sig. $(0.001)<0.05$. This means that the financial literacy variable has an effect on consumptive behavior.

3. The variables of the use of social media on consumptive behavior are known to be sig. $(0.000)<0.05$. This means that the variable of social media use affects consumptive behavior. 
Based on the results of the $\mathrm{F}$ test, it can be concluded that there is a significant effect between the independent variables (more than two) together on the dependent variable. Simultaneous test results between X1. X2 and X3 to Y produce calculated $\mathrm{F}$ of 9.830 with a significance of $0.000<0.05$. This means that the independent variables consisting of income, financial literacy and the use of social media together have a significant effect on the dependent variable, namely consumptive behavior.

Determination test results obtained that the value of the coefficient of determination (R2) is 0.247 . This means that the influence of income levels, financial literacy, and the use of social media on the consumptive behavior of PNS teachers in Sabak Auh District is 24.7\%. While the remaining $75.3 \%$ is influenced by other variables that are not included in the regression model.

The results showed that the income level of PNS teachers in Sabak Auh District, Siak Tegolong Regency was very high, exceeding 3,500,000.00 per month referring to the category of BPS (2015). After analyzing the data, it was found that the level of income had no effect on the consumptive behavior of PNS teachers in Sabak Auh District. It has not been proven that the influence of teacher income levels in the study is caused by many other factors that are considered by teachers in consumption,

The results of this study are not in line with research conducted by several previous studies which state that income levels partially have a significant effect on consumptive behavior (Ikhwani Ratna \& Hidayati Nasrah, 2015; Gumanti, 2017; Sutriati et al, 2018). The teacher's income has not had a significant effect on consumptive behavior due to the teacher's ability to control himself in purchasing goods due to the level of knowledge obtained from the education of the teachers. Even though the teacher's income is relatively higher, the knowledge he has from his education makes the teacher able to control himself not to behave consumptively. The better the education, the better the way of thinking and personality (Wahyuni, 2019)

The results of the research conducted during the Covid 19 pandemic contradicted the opinion of the lecturer of the Faculty of Economics and Business, Universitas Airlangga, Dr. Wisnu Wibowo, who stated that the WFH and PSBB conditions that were implemented in a number of areas during the Covid 19 pandemic caused a psychological demonstration effect of increasing consumer behavior due to the increased intensity of internet use, resulting in frequent viewing of online shopping sites, boredom due to limited space, and the ease of online shopping facilities. offered (kompas.com, 2020).

Furthermore, the results of the study indicate that the financial literacy of the respondents is included in the low category, this proves that the teachers do not have sufficient general knowledge of finance, savings and loans, insurance, and investment. This lack of knowledge will have an impact on making financial decisions in everyday life, they will find it difficult to make decisions that are most beneficial to their economic well-being (financial well being) such as having 
excessive consumption debt guaranteed by an employee decree. Students who have low knowledge will make wrong decisions in their financial activities. Students who have a high level of literacy ability will make the right decisions in consuming, because in this case they take into account which goods or services they need first. financial literacy has a negative effect on student consumptive behavior. when financial literacy increases, consumptive behavior will decrease" (Chen \& Volpe. 1998; Imawati et al., 2013; Dikria \& Mintarti, 2016; Kumalasari, 2019). This shows the importance of the community, especially teachers, to have good knowledge of economic concepts, especially about finance and their application in everyday life. Financial literacy is something that must be owned by everyone, because today we are faced with various choices of both service products and financial services (Wulandari, 2015).

The results of this study indicate that the respondents' use of social media is included in the low category, this proves that the teachers are not too able to regulate the use of social media well enough. In the next variable, namely the influence of the use of social media on the consumptive behavior of teachers, the research results obtained that the use of social media has a significant positive effect on the consumptive behavior of PNS teachers in Sabak Auh District, Siak Regency. This means that the use of social media owned by PNS teachers in Sabak Auh District, Siak Regency is a factor that is able to provide a significant influence on consumer behavior. The findings show that the percentage of the influence of the use of social media on consumption behavior is $27.6 \%$, meaning that the use of social media contributes to a greater influence on consumptive behavior than the factors of income and financial literacy.

The results of this study are in line with research conducted by several previous researchers who explained that the use of social media had a positive and significant effect on the consumptive behavior of students, meaning that the higher the use of social media, the higher the consumptive behavior of students. the lower the consumptive behavior of students (Hidayanti et al, 2017; Hidayatun, 2015; Sari \& Subaida, 2019; Khoiriyah, 2020))

Overall level of income, financial literacy, and use of social media are factors that influence consumptive behavior. Someone who has a fairly high level of income, the level of use of social media is also high so that they often access information about a product if the level of financial literacy is inadequate, they will easily make wrong decisions in consumption so that it has the potential to increase consumptive behavior. The three variables are mutually sustainable in influencing a person's influence in consumption.

\section{Conclusion}

Based on the results of the analysis carried out, it can be concluded that the level of income does not affect the consumptive behavior of PNS teachers in Sabak Auh District, Siak. So that the first hypothesis is rejected. Financial literacy has a negative and significant effect on the consumptive behavior of PNS teachers in Sabak Auh District, Siak. So the second hypothesis is accepted. Thus, the higher 
the student's lifestyle, the higher the student's consumptive behavior. The use of social media has a positive and significant effect on the consumptive behavior of PNS teachers in Sabak Auh District, Siak. The level of income, financial literacy and use of social media simultaneously affect the consumptive behavior of civil servant teachers in Sabak Auh District, Siak. For Respondents (Teachers), it is wiser to use the income you have so you don't become a consumptive actor. The teacher should improve their financial literacy in order to manage finances better. It is wiser to use social media to become smart consumers who can distinguish between wants and needs, not easily persuaded by advertisements. Social media can also be used for knowledge about finance so that the currently low level of financial literacy can increase. For further research, in order to add other variables besides the two independent variables in the study or to study more deeply about financial literacy, not only cognitive aspects but also financial attitudes and financial behavior that can affect consumptive behavior.

\section{References}

Achmad, S.R. (2012). Hubungan Gaya Hidup Konsumtif Dengan Harga Diri Mahasiswa Fakultas Psikologi Universitas Indonesia. (Online). http://lontar.ui.ac.id/file?file=digital/20308770S\%2043109\%20 Hubungan\%20gaya-full\%20text.pdf (diakses 19 Desember 2020)

Anggraeni, E., \& Setiaji, K..(2018). ,Pengaruh Media Sosial dan Status Sosial Ekonomi Orang Tua Terhadap Perilaku Konsumtif Mahasiswa. ,Economic Education Analysis Journal, 7(1), 172-180.

Antow, F.T. Angelina. (2016). Pengaruh Layanan Online Shop (Belanja Online) Terhadap Konsumerisme Siswa SMA Negeri 9 Manado, Vol. 5, No. 3, Hal. 6.

Chen, H. \& Volpe, R. P., (1998), An Analysis of Personal Financial Literacy Among College Students. Financial Services Review 7(2): 107-128.

Chita, M. C. R., David, L. \& Pali C (2015) Hubungan antara Self-Control dengan Perilaku Konsumtif Online Shopping Produk Fashion pada Mahasiswa Fakultas Kedokteran Universitas Sam Ratulangi Angkatan 2011. Jurnal eBiomedik, 3(1): 297-302.

Dikria, O \& Mintarti, S.U. (2016). Pengaruh Literasi Keuangan dan Pengendalian Diri Terhadap Perilaku Mahasiswa Jurusan Ekonomi Pembangunan Fakultas Ekonomi Universitas Negeri Malang Angkatan 2013, Jurnal Pendidikan Ekonomi, Vol.09, No.2. 133. p-ISSN: 0216-7085, e-ISSN: 2579-3780

Gumanti,D. Sari P.M. \& Putri,Y.(2017). Pengaruh Pendapatan, Kelompok Referensi, Literasi Ekonomi, dan Sertifikasi Guru Terhadap Perilaku Konsumsi Guru SD, SMP, dan SMA di Kecamatan Gunung Talang Kabupaten Solok, dalam Jurnal Journal of Economic and Economic Education Vol.6 No.1 (55-65).

Hidayanti, Riyanto., \& Nugroho A. (2017) Pengaruh Penggunaan Media Sosial, Konsep diri dan Financial Literacy terhadap Perilaku Konsumtif, Proceeding Seminar Nasional KeIndonesiaan IV Tahun 2017 "Multikulturalisme Dalam Bingkai Ke-Indonesiaan Kontemporer" 
Ikhwani, R., \& Nasrah, H. (2015).Pengaruh Pendapatan dan Tingkat Pendidikan terhadap Perilaku Konsumtif Wanita Karir di Lingkungan Pemerintah Propinsi Riau, Jurnal Marwah, Vol. XIV No. 2.

Imawati, I., Susilaningsih \& Ivada, E (2013) Pengaruh Financial Literacy terhadap Perilaku Konsumtif Remaja Pada Program IPS SMA Negeri 1 Surakarta Tahun Ajaran 2012/ 2013. Jurnal Pendidikan Ekonomi, 2(1): 48-58.

Khoiriyah, U. (2020). Pengaruh Peer Group, Literasi Ekonomi dan Penggunaan Media Sosial terhadap Perilaku Konsumtif Siswa Jurusan IPS SMA Negeri di Kabupaten Brebes, Thesis: Fakutas Pendidikan Ekonomi, Univesitas Negeri Semarang.

Kompas.com, 2020. Pakar Unair: Pandemi Covid-19 Membuat Masyarakat Cenderung Lebih Konsumtif https://edukasi.kompas.com/read/2020/ 07/17/161944571/pakar-unair-pandemi-covid-19-membuat-masyarakatcenderung-lebih-konsumtif, (Diakses 19 Desember 2020)

Kumalasari, D dan Soesilo, Y.H. (2019). Pengaruh Literasi Keuangan, Modernitas Individu, Uang Saku dan Kontrol Diri terhadap Perilaku Konsumtif Mahasiswa Prodi S1 Pendidikan Ekonomi Angkatan Tahun 2016 Fakultas Ekonomi Universitas Negeri Malang. Jurnal pendidikan Ekonomi, 12 (1), 61-71

Kurniadi, R, Suarman., \& Syahza, A., (2019). Financial Literacy of Bidikmisi Scholarship Recipient Students. Journal of Educational Sciences Vol. 3: 292-302

Kurniadi, R, Syahza, A dan Suarman., (2018). Profil Literasi Keuangan Mahasiswa Penerima Beasiswa Bidikmisi, dalam SOROT: Jurnal Ilmuilmu Sosial Volume 13, Nomor 2, Oktober 2018: 73-84

Mawo, T., P. Thomas, dan S. Sunarto. (2017). Pengaruh Literasi Keuangan, Konsep Diri dan Budaya terhadap Perilaku Konsumtif Siswa SMAN 1 Kota Bajawa. Journal of Economic Education 6(1): 60-65.

Prihastuti, D.R, dan Rahayuningsih, S. (2018). Pengaruh Financial Literacy, Financial Behavior, Financial Attitude, dan Demografi Terhadap Perilaku Konsumtif (Studi Pada Mahasiswa Strata I Fakultas Ekonomi Universitas 17 Agustus 1945 Surabaya), Jurnal Hasil Penelitian LPPM Untag Surabaya, 03 (2), 121 - 134.

Sari, R.K., \& Subaida, I. (2019). Pengaruh Medi Sosial terhadap Perilaku Konsumtif Online Shopping pada Mahasiswa Fakultas Ekonomi Universitas Abdurachman Saleh Situbondo. Jurnal Penelitian Cermin Vol.3 No 1

Sutriati., Kartikowati,S \& Riadi RM. (2018). Pengaruh Pendapatan dan Gaya Hidup terhadap Perilaku Konsumtif pada Mahasiswa Jurusan Ilmu Pengerahuan Sosial FKIP UNRI, dalam Jurnal JOM FKIP Vol 5 :

Tsalitsa, A. (2016). Analisis Pengaruh literasi Keuangan dan faktor Demografi terhadap Pengambilan Kredit pada PT. Columbia Cabang Kudus. Media Ekonomi dan Manajemen 31(1): 1-13.

Wahyuni, D., Caska, \& Indrawati, H. (2019). Analisis Tingkat Pendidikan Pemilik Usaha dan Faktor-Faktor yang Mempengaruhi Keberhasilan Usaha BerbasisSagu UMKM di Kabupaten Kepulauan Meranti. Jurnal Ilmu Pendidikan ,3(2) , 216-226. 
Wulandari, D., \& Narmaditya, S. B. (2015). Dampak Literasi Keuangan Pada Akses Layanan Keuangan: Studi Pada Kepemilikan Polis Asuransi di Malang. JESP-Vol. 7, ISSN 2086-1575

How to cite this article:

Hidayati, N., Kartikowati, S., \& Gimin. (2021). The Influence of Income Level, Financial Literature, and Social Media Use on Teachers' Consumption Behavior. Journal of Educational Sciences, 5(3), 479-490. 